\title{
Pembangkit Listrik Tenaga Ombak Laut atau Angin Laut dengan Pengendali Gravitasi Bumi
}

\author{
Wintazon $^{1}$, Anang Setyo Pramudianto ${ }^{2}$, Eko Nur Hidayat ${ }^{3 *}$ \\ ${ }^{1}$ J1 Bukit Anyelir 5 No 312 Perum Sendang Mulyo Kec, Tembalang Semarang \\ wintazonmath93@gmail.com \\ ${ }^{2}$ PT. Wijaya Karya, Tbk \\ Jl. DI. Panjaitan No.Kav 9-10, RT.1/RW.11, Cipinang Cempedak, Jatinegara, Jakarta Timur \\ 13340 \\ setyop.anang98@yahoo.com \\ ${ }^{3}$ Program Studi Teknika AKPELNI \\ Jln. Pawiyatan Luhur II/17 Bendan Dhuwur Semarang 60235 INDONESIA \\ 3*ekonurhidayat@akpelni.ac.id
}

\begin{abstract}
Abstrak
Intisari - Kebutuhan energi bagi kehidupan manusia di dunia adalah termasuk kebutuhan terpenting dan pokok, dimana energi selalu dibutuhkan dalam kehidupan manusia. Pertumbuhan penduduk dunia yang semakin pesat membutuhkan ketersediaan energi dan yang sangat besar, sehingga di butuhkan penyediaan energi yang besar atau penyediaan energi yang terbarukan (renewable) dan Energi yang ramah lingkungan (Eco-Friendly). Alternatif Penyediaan Energi yang di tawarkan adalah Pemanfaatan Tenaga Ombak Laut atau Angin Laut dengan memanfaatkan gravitasi Bumi sebagai Pembangkit Tenaga Listrik.

Kata Kunci : Energi, Energi terbarukan dan Energi ramah lingkungan
\end{abstract}

Abstract - Energy needs for human life in the world include the most important and essential needs, where energy is always needed in human life. The rapid growth of world population requires the availability of energy and very large, so that it requires a large supply of energy or the provision of renewable energy and environment-friendly energy. Alternative Energy Supply that is offered is Sea Wave Power Utilization or Sea Wind by utilizing Earth's gravity as a Power Plant. Key Words: Energy, Renewable Energy and Eco-Friendly Energy

\section{PENDAHULUAN}

A. Latar Belakang .

Kebutuhan energi bagi kehidupan manusia di dunia adalah termasuk kebutuhan terpenting dan pokok, dimana energi selalu dibutuhkan dalam kehidupan. Dalam perkembangan kehidupan manusia sumber energi yang dimanfaatkan bermacam-macam antara lain: energi matahari, minyak bumi, batubara, angin, gelombang laut, kayu bakar atau material yang bisa di bakar, energi nuklir, energi hasil proses reaksi kimia, dll.

Dalam perkembangannya penggunaan energi alam diatas mengalami berbagai kendala dan dampak atau efek pencemaran lingkungan. Begitu juga keterbatasan energi alam tersebut. Pertumbuhan penduduk dunia yang semakin pesat membutuhkan ketersediaan energi dan yang sangat besar. Peradaban manusia di zaman 
modern membuat exploitasi energi yang sangat besar yang mengakibatkan kerusakan lingkungan. Dari fenomena alam tersebut disimpulkan agar kita mengatur energi dan memanfaatkan energi yang ada di alam yang ramah lingkungan sehingga dibutuhkan penelitian dan penemuan yang dapat mengkonversi energi yang dilakukan secara komperhensif. Dalam Hal ini penulis mengambil Energi altenatif yaitu pemanfaatan energi ombak laut atau angin laut adalah salah satu solusi alternatif untuk memenuhi kebutuhan energi yang dibutuhkan manusia. Hal yang mendasari Pemilihan sumber energi terbarukan dari tenaga ombak laut atau angin laut adalah letak geografis Indonesia. Dengan kondisi Geografis Indonesia yang terletak di antara 2 Benua dan 2 Samudra menyebabkan Indonesia dikelilingi oleh lautan yang luas dengan Ombak yang besar di perairan laut sebelah selatan, sehingga sangat relevan untuk mengembangkan Pembangkit Listrik Tenaga Ombak Laut atau Angin Laut.

\section{B. Tinjauan Pustaka}

Gelombang laut adalah pergerakan naik dan turunnya air laut dengan arah tegak lurus permukaan air laut yang membentuk kurva atau grafik sinusoida [6]. Pemanfaatan gelombang laut sebagai pembangkit listrik terbarukan yang hemat energi dan ramah lingkungan telah dilakukan beberapa peneliti sebelumnya. Sistem konverter yang pernah dikembangkan di Eropa sangat beragam [4]. Pembangkit Listrik Tenaga Gelombang Laut secara umum bekerja dengan mengkonversi energi gelombang laut menjadi energi mekanik, kemudian energi mekanik tersebut selanjutnya dikonversi menjadi energi listrik. Permasalahan utama dalam pengembangan Pembangkit Listrik Tenaga Gelombang Laut adalah fluktuatifnya gelombang laut yang dapat menyebabkan tidak optimalnya sistem ini pada saat gelombang memberi gaya dorong yang kecil. Pada saat gaya dorong yang bersumber dari gelombang besar maka sistem dapat bekerja secara optimal tetapi proses ini tidak terjadi secara kontinu [1]. Gelombang laut memiliki energi potensial dan kinetik yang dapat dihitung dengan persamaan dari Kim Neilsen. Dengan menggunakan persamaan persamaan tersebut maka dapat diperoleh berapa energi yang terdapat di dalam gelombang tersebut [3]. Diperkirakan potensi laut mampu memenuhi empat kali kebutuhan listrik dunia, sehingga tidak mengherankan apabila berbagai negara maju telah berlomba memanfaatkan energi ini .

\section{Maksud dan Tujuan}

Penelitian ini dimaksudkan untuk memanfaatkan sumber daya ombak atau angin laut sebagai energi alternative yang ramah lingkungan dengan tujuan mengoptimalkan hasil energi listrik dengan konversi energi ombak atau angin laut sebagai tenaga penggerak generator untuk mencukupi kebutuhan energi listrik nasional.

II. METODOLOGI
Metodologi penelitian merupakan
sebuah cara untuk mengetahui hasil
dari sebuah permasalahan yang
spesifik, dimana permasalahan tersebut
disebut juga dengan permasalahan
penelitian. Dalam Metodologi, peneliti
selalu berusaha untuk mencari
pertanyaan yang diberikan dengan cara-
cara yang sistematis yang digunakan
dan berupaya untuk mengetahui semua
jawaban sampai dapat mengambil


kesimpulan. Jika penelitian tidak dilakukan secara sistematis pada masalah, akan lebih sedikit kemungkinannya untuk dapat mengetahui hasil akhir. Untuk menemukan atau menjelajahi pertanyaan penelitian, peneliti akan menghadapi berbagai permasalahan, dimana semua itu baru dapat diselesaikan secara efektif jika menggunakan metodologi penelitian yang benar (Industrial Research Institute, 2010).

Metodologi Penelitian yang digunakan:

1. Pengamatan

2. Menyimpulkan obyek masalah

3. Mengambil data

4. Mengolah data

5. Membuat model

6. Eksperimen

7. Evaluasi

8. Kesimpulan

Dan Dilakukan Dengan PDCA : PlanDo-Check-Action sampai didapatkan hasil yang diharapkan.

\section{HASIL DAN PEMBAHASAN}

Definisi dari Pembangkit Listrik adalah adalah salah satu bagian dari sistem tenaga listrik, pada Pembangkit Tenaga Listrik terdapat peralatan elektrikal, mekanikal, dan bangunan kerja. Terdapat juga komponen-komponen utama pembangkitan yaitu generator, turbin yang berfungsi untuk mengkonversi energi (potensi) mekanik menjadi energi (potensi) listrik.

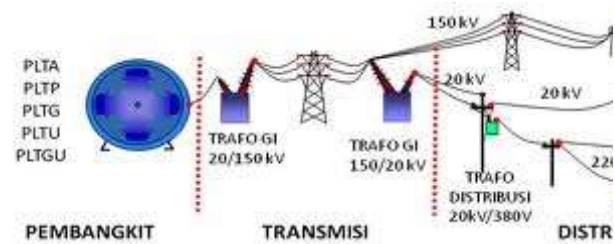

Gambar 3.1 Distribusi Listrik
Pada gambar 3.1 diatas diilustrasikan bahwa listrik yang dihasilkan dari pusat pembangkitan yang menggunakan energi potensi mekanik (air, uap, minyak bumi, gas alam, panas bumi, angin,nuklir, dll) untuk menggerakkan turbin yang porosnya dikopel/digandeng dengan generator. dari generator yang berputar menghasilkan energi listrik. Energi listrik yang dihasilkan disalurkan ke gardu induk melalui jaringan transmisi, kemudian langsung di distribusikan ke konsumen melalui jaringan distribusi.

A. Bagian-bagian Pembangkit Tenaga Listrik

1). Penggerak utama (prime mover)

- Mesin diesel

- Turbin (air, gas, uap, angin)

- Beserta komponen dan perlengkapan lainnya (kondenser, boiler, dll)

2). Komponen listrik

- Generator dan perlengkapannya

- Transformator

- Peralatan proteksi

- Saluran kabel, busbar, dll

3). Komponen sipil

- Prasarana dan sarana sipil (pondasi peralatan, jalan, cable dutch, dll)

- Gedung kontrol

4). komponen mekanis

- Peralatan bantu, peralatan pendingin, peralatan proteksi, dll. 
B. Skema Pembangkit Tenaga Angin Laut atau Ombak Laut dengan Pengendali Gravitasi Bumi

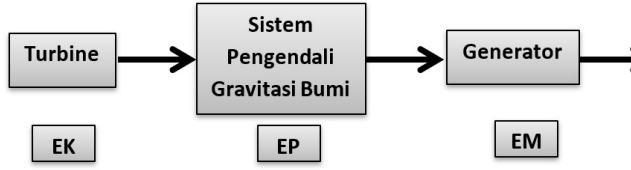

Gambar 3.2 : Skema Pembangkit Listrik Tenaga Angin Laut atau Ombak Laut dengan Pengendali Gravitasi Bumi

Sistem Pengendali Gravitasi Bumi adalah Sebuah Model Mesin yang merubah (mengkonversi) Energi gerak Kinetik dari Turbine di simpan menjadi Energi Potensial. Dengan menggunakan sistem hidrolik yang memindahkan/ memompa Fluida cair untuk menggerakkan beban sehingga didapatkan beda ketinggian yang menyimpan energi potensial. Setelah Energi potensial maksimum di rubah kembali menjadi Energi Mekanik dari Generator.

C. Alur Proses Pembangkit Listrik Tenaga Ombak Laut atau Angin Laut dengan Sistem Pengendali Gravitasi Bumi :

1). Turbine :

Merubah gerak kinetik dari gerak angin atau ombak yang arahnya dan kecepatannya berubah-ubah menjadi gerak lurus berubah beraturan.

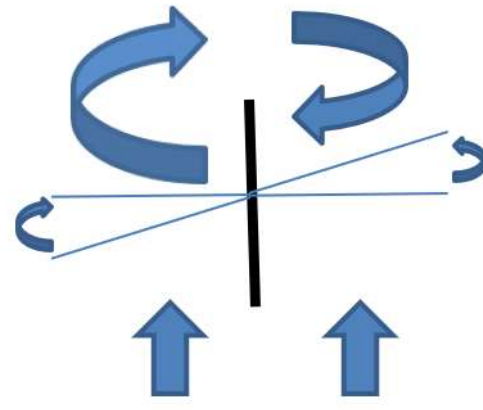

Gambar 3.3 konsep turbin

Turbin yang paling sederhana terdiri dari sebuah bagian yang berputar disebut rotor, yang terdiri atas sebuah poros/shaft dengan sudu-sudu atau blade yang terpasang disekelilingnya. Rotor tersebut berputar akibat dari tumbukan aliran fluida atau berputar sebagai reaksi dari aliran fluida tersebut. Putaran rotor akan diarahkan untuk menggerakkan hidrolik.

Menurut [2] model perambatan gelombang mengikuti pola grafik sinus.

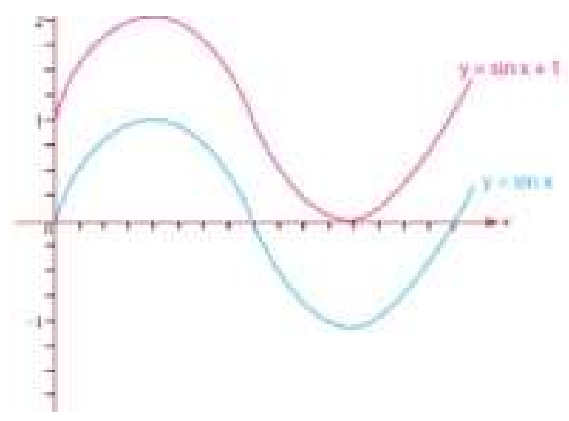

Gambar 3.4 : grafik perambatan gelombang 
Menurut [5] aliran fluida akan berlaku :

1). Debit fluida

Debit adalah jumlah aliran persatuan waktu.

Dalam persamaan dinyatakan dengan :

$Q=\frac{V}{t}$

dimana

$\mathrm{Q}=$ Kapasitas/Debit $\left(\mathrm{m}^{3} / \mathrm{dt}\right)$.

$\mathrm{V}=$ Volume Fluida $\left(\mathrm{m}^{3}\right)$.

$\mathrm{t}=$ Waktu (dt).

Atau

$\mathrm{Q}=\mathrm{A} \times \mathrm{V}$

dimana

$\mathrm{A}=$ Luas $\left(\right.$ meter $\left.^{2}\right)$.

$\mathrm{V}=\operatorname{Kecepatan}$ Fluida (m/dt).

2). Persamaan Boyle:

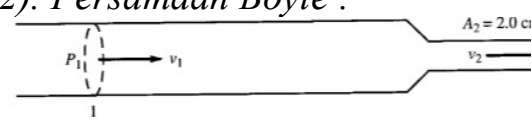

Gambar 3.5 : Aliran fluida pada pipa yang berbeda diameter

$\mathrm{P}_{1} \times \mathrm{V}_{1}=\mathrm{P}_{2} \times \mathrm{V}_{2}$

dimana

$\mathrm{P}=$ Tekanan

$\mathrm{V}=$ Volume

\section{3).Persamaan Kontinuitas :}

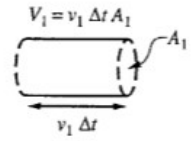

(a)

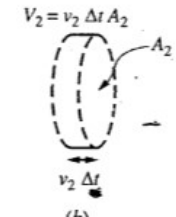

Gambar 3.6 : Aliran fluida pada luas penampang yang berbeda dan kecepatan berbeda

$\mathrm{Q}_{1}=\mathrm{Q}_{2}$
$A_{1} \times V_{1}=A_{2} \times V_{2}$

2). Sistem Pengendali Gravitasi

Bumi :

adalah Sebuah Model Mesin

yang merubah

(mengkonversi) Energi gerak

Kinetik dari Turbine di

simpan menjadi Energi

Potensial. Dengan

menggunakan sistem hidrolik

yang memindahkan/

memompa Fluida cair untuk

menggerakkan beban

sehingga didapatkan beda

ketinggian yang menyimpan

energi potensial. Setelah

Energi potensial maksimum di rubah kembali menjadi

Energi Mekanik dari

Generator.

Persamaan / rumus dasar fluida hidrolis :

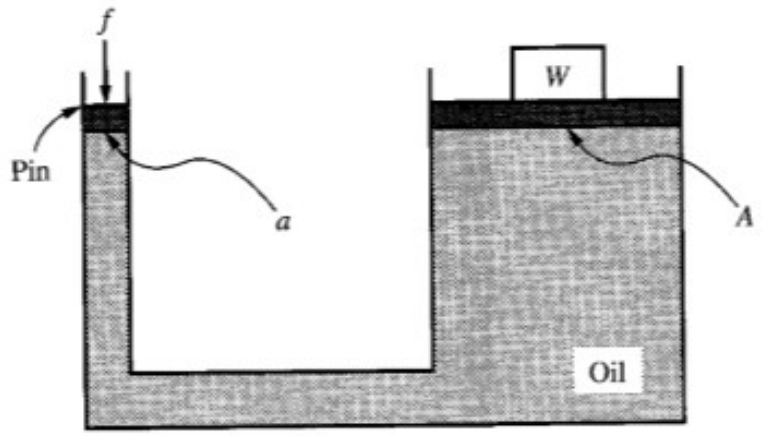

Gambar 3.7 : konsep hidrolis mengangkat beban

$f=W\left(\frac{a}{A}\right)$

atau 


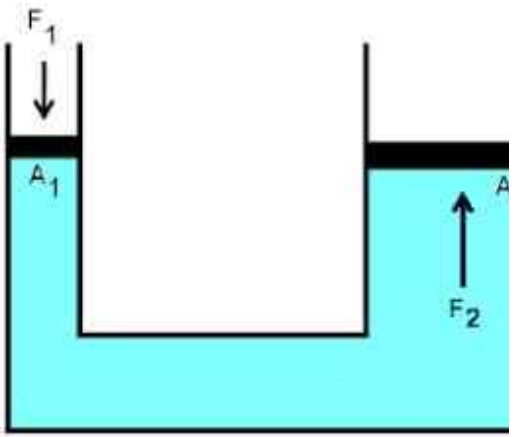

Gambar 3.8 : konsep gaya hidrolis

$\frac{F_{1}}{F_{2}}=\frac{A_{1}}{A_{2}}$

Tekanan adalah gaya persatuan luas penampang.

Dalam persamaan dinyatakan dengan :

$P=\frac{F}{A}$

dimana

$\mathrm{P}=$ Pressure/ Tekanan

(Pascal).

$\mathrm{F}=$ Force/gaya (Newton).

$\mathrm{A}=$ Area/luas $\left(\right.$ Meter $\left.^{2}\right)$

Tekanan pada $F_{1}$ bersumber dari putaran turbin, digunakan untuk mengangkat beban $\mathrm{W}$ sesuai gambar 3.7.

Konversi satuan :

1 Pascal $=1$ Newton $/$ Meter2 $(\mathrm{Pa}=\mathrm{N} / \mathrm{M} 2)$

$$
\begin{aligned}
1 \mathrm{Bar} & =105 \mathrm{~Pa} \\
& =100 \mathrm{kPa} \\
& =14.7 \quad \text { Psi } \\
(\mathrm{Lbf} / \mathrm{in} 2) & \\
& =1 \mathrm{Kgf} / \mathrm{Cm} 2 \\
1 \mathrm{M} 3 / \mathrm{dt} & =60 \mathrm{M} 3 / \text { menit } \\
1 \mathrm{M} 3 / \text { menit } & =1000 \quad \mathrm{LPM} \\
\text { (liter/menit) } &
\end{aligned}
$$

Hukum Pascal menyatakan bahwa tekanan yang diberikan kepada fluida di dalam ruang tertutup akan diteruskan ke segala arah [7]. Hukum Pascal diterapkan dalam dongkrak hidrolik, pompa hidrolik, mesin pengepres hidrolik, kursi pasien dokter gigi, dan rem piringan hidrolik pada mobil. Hukum Pascal berdasarkan gambar dapat dirumuskan sebagai berikut :

$\mathrm{P}_{1}=\mathrm{P}_{2}$

$\frac{F_{1}}{A_{1}}=\frac{F_{2}}{A_{2}}$

Keterangan :

$$
\begin{aligned}
\mathrm{F} 1, \mathrm{~F} 2= & \text { gaya } \\
& \begin{array}{r}
\text { yang } \\
\text { penampang } 1 \text { dan }
\end{array} \\
& 2(\mathrm{~N}) \\
\mathrm{A} 1, \mathrm{~A} 2= & \text { luas penampang } \\
& 1 \text { dan } 2(\mathrm{~m} 2) \\
\mathrm{r} 1, \mathrm{r} 2= & \text { jari-jari } \\
& \text { penampang } 1 \text { dan } \\
& 2(\mathrm{~m}) \\
\mathrm{d} 1, \mathrm{~d} 2= & \text { diameter } \\
& \text { penampang } 1 \mathrm{dan} \\
& 2(\mathrm{~m})
\end{aligned}
$$

Potaran rotor turbin akan menggerakkan hidrolik mengangkat beban W, setelah dicapai ketinggian maksimal yang dibutuhkan berlaku hukum Energi potensial : 


$$
\begin{aligned}
& \mathrm{EM}=\mathrm{EP}+\mathrm{EK} \\
& \mathrm{EM} 1=\mathrm{EM} 2
\end{aligned}
$$

Dimana :

EM : energi mekanik

EK : energi kinetic

EP : energi potensial

Pada saat Ep Maksimum, $\mathrm{Ek}=0$ sehingga didapat persamaan

$$
\mathrm{Em}=\mathrm{Ep}
$$

Setelah melewati hidrolik, maka grafik energinya akan menjadi linier, dalam bentuk grafik fungsi $y=a x$ :

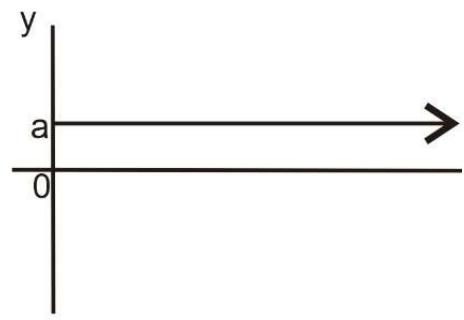

Gambar 3.9 : grafik energi setelah melewati pengendali grafitasi bumi

\section{3). Generator:}

Generator akan digerakkan dengan pully Transmisi ketika Ep dalam keadaan Maksimum, dimana Em $=\mathrm{Ep}$ akan dikonversikan dari $\mathrm{Ep}=$ EL

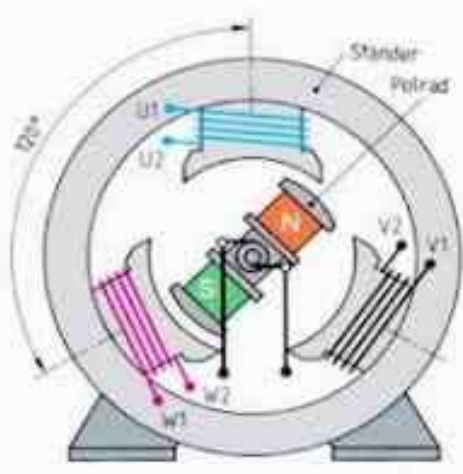

Gambar 3.10 : Generator

\section{4). Simulasi perhitungan:}

Untuk menghitung berapa beban Sistem Pengendali Gravitasi Bumi yang dibutuhkan untuk turun dalam ketinggian 10 meter dalam 10 menit untuk menggerakkan generator 1 M Watt selama 10 menit.

$\mathrm{EM}=\mathrm{EP}+\mathrm{EK}$

$\mathrm{EM} 1=\mathrm{EM} 2$

Ketika EP max, Maka EP = EL

$\mathrm{EL}=1000.000 \times 10$ menit $E L=10.000 .000$ Watt Menit

$\mathrm{Ep} \quad=\mathrm{mxg \times h}$

$=\mathrm{EL}$

$\mathrm{m} \quad \mathrm{x} \quad 10 \quad \frac{m}{d t^{2}} \mathrm{x} \quad 10 \quad \mathrm{~m}=$ 10.000.000 watt menit

$100 \mathrm{~m}=10.000 .000$

$\mathrm{m}=100.000$

$\mathrm{m}=100$ Ton

$\mathrm{P} \quad=1$ Mega watt

$$
=1.000 .000
$$

Joule/detik

Membutuhkan putaran 1500Rpm

$=1500 / 60 \mathrm{Rad} / \mathrm{detik}$

$1500 \mathrm{Rpm}=25 \mathrm{Rad} / \mathrm{detik}$ 


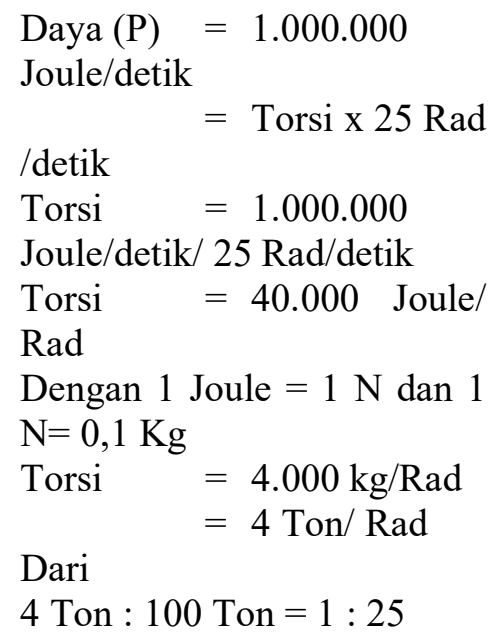

\section{KESIMPULAN}

Energi yang dihasilkan dari energi alam mengikuti pola grafik fungsi $\mathrm{Y}=\operatorname{Sin}$ a $\mathrm{X}$, setelah melewati system pengendali grafitasi bumi, maka energi yang dihasilkan mengikuti grafik gerak lurus berubah beraturan dan akan disimpan dalam sistem pengendali gravitasi bumi. Energi tersebut dapat diatur sesuai dengan kebutuhan dan dengan biaya yang sangat murah karena mengurangi kehilangan energi.

\section{UCAPAN TERIMA KASIH}

Terima kasih kepada Direktur AKPELNI yang telah memberikan kesempatan melakukan penelitian ini sekaligus menyediakan anggaran pelaksanaan penelitian. Terima kasih juga kami ucapkan kepada pimpinan PT Wijaya Karya tbk. yang telah mengijinkan salah satu karyawannya terlibat dalam penelitian ini. Kepada panitia Seminar Nasional dan Mechanical Expo Fakultas Teknik UKI yang telah memberikan kesempatan menyampaikan gagasan kami dalam seminar nasional. Tidak lupa ucapan terima kasih juga kami ucapkan kepada semua pihak yang tidak dapat kami sebutkan satu per satu, yang telah memberikan dukungan baik data, moral maupun finansial sehingga penelitian ini dapat terlaksanan.

\section{REFERENSI}

[1]. Abdullatif R.F, J. Aminuddin, dan A.N. Aziz.2013. Pengembangan Sistem Komputasi dan Instrumentasi Fisis dalam Perancangan Pembangkit Listrik Tenaga Gelombang Laut Sistem Pendulum. Seminar Nasional Pengembangan Pedesaan, LPPMUNSOED September 2013.

[2] Aminuddin J, Sehah, and Sunardi.2011. Pemodelan Gelombang Laut untuk Menunjang Pelestarian Pulau Nusakambangan. Proc. Seminar Nasional Pengembangan Sumber Daya Pedesaan dan Kearifan Lokal Berkelanjutan, Nopember 17-18. UNSOED, Purwokerto: 70-82.

[3] Budi Murdani, 2008, "Analisa Rancang Bangun Pembangkit Listrik Tenaga Gelombang Laut dengan Sustem Oscillating Water Column di Pantai Baron Yogyakarta." Jakarta, 2008.

[4] Drew B, A.R. Plummer, and M.N. Sahinkaya.2009. A Review of Wave Energy Converter Technology, Journal of Power and Energy, Vol 223, No 782. 887-902.

[5] Halpern, Alvin. 1995. Theory and Problems of Beginning Phisycs I : Mecanics and Heat. Schaum's Outline Series. Mc Graw Hill

[6] Kurniawan. R., Habibie.M. N., dan Suratno., 2011. Variasi Bulanan Gelombang Laut di Indonesia. Jurnal Meteorologi dan Geofisika, 12 (3), pp. 221232.

[7] Walker, Jearl.Fundamentals of Phisycs. $8^{\text {th }}$ edition. . pp. 462 